\title{
ADMINISTRATIVE COSTS AND EQUILIBRIUM CHARGES WITH INDIVIDUAL ACCOUNTS
}

\author{
Peter Diamond
}

Working Paper 7050

http://www.nber.org/papers/w7050

\author{
NATIONAL BUREAU OF ECONOMIC RESEARCH \\ 1050 Massachusetts Avenue \\ Cambridge, MA 02138 \\ March 1999
}

The views expressed in this paper are those of the authors and do not reflect those of the National Bureau of Economic Research.

(1) 1999 by Peter Diamond. All rights reserved. Short sections of text, not to exceed two paragraphs, may be quoted without explicit permission provided that full credit, including ${ }^{\circledR}$ notice, is given to the source. 
Administrative Costs and Equilibrium

Charges with Individual Accounts

Peter Diamond

NBER Working Paper No. 7050

March 1999

\section{ABSTRACT}

There are many individual account proposals. For government-organized accounts, the government arranges for both record-keeping and investment management. For privately-organized accounts, individuals directly select private firms to do these tasks.

The government spreads the costs of government-organized accounts among accounts, outside sources of revenue, employers and workers. With privately-organized accounts, equilibrium prices reflect selling costs as well as administrative costs. Thus, government-organized accounts are organized on a group basis while privately-organized accounts are organized on an individual basis. In financial and insurance markets generally, the group and individual markets function very differently and yield different pricing structures.

The paper describes a low cost/low services government-organized plan and estimates that it might cost $\$ 40-50$ per worker per year. The nature of equilibrium with privately-organized accounts is discussed, with the conclusion that the costs would be very high compared to the cost of government organization.

Peter Diamond Department of Economics MIT

Room E52-344

50 Memorial Drive Cambridge, MA 02139 and NBER

pdiamond@mit.edu 
Individual account proposals come with a vast variety of different structures and details. There are many different ways in which a discussion of individual accounts might be organized. For analytical discussion of administrative charges, a central distinction is between government-organized accounts and privately-organized accounts. The term government-organized accounts will be used to denote individual account systems in which the government arranges for both the record-keeping for the accounts and the investment management for the funds in the accounts -- whether these functions are performed by government agencies or by private firms under contract to the government. An example of government-organized accounts is the federal Thrift Savings Plan (TSP), a pension plan which contracts with a government agency to perform record-keeping and with a private firm to do fund management. The term privately-organized accounts will be used to denote individual account systems in which individuals directly select private firms to do the record-keeping and investment management. An example is individual retirement accounts (IRA's), where individuals select their own private financial institution.

With government-organized accounts two questions are how much it costs to run the system and how the government allocates those costs among the different accounts, and possibly to outside sources of revenue. There are also costs that may fall on employers and workers. With privately-organized accounts we must ask about equilibrium prices and their relationship to selling costs as well as the costs of record-keeping and investment management. Again, there are also costs that may fall on employers, workers and the government. Since

1 Prepared for NBER Conference on the Administrative Costs of Individual Accounts As Part of Social Security Reform, December 4, 1998

2 This paper draws heavily on the material developed by the Panel on Privatization of Social Security of the National Academy of Social Insurance. I am grateful to my colleagues on the Panel and its staff for illumination on these issues. They are not responsible for my interpretations. While I have marked extensive quotations from the Report, I have also drawn liberally and verbatim in smaller doses, with permission and without repeated acknowledgements. 
the government may be purchasing services from private providers, another way to see this distinction is that government-organized accounts are organized on a group basis while privately-organized accounts are organized on an individual basis. As with financial and insurance products generally, the group and individual markets function very differently and yield different pricing structures. ${ }^{3}$

A central element in thinking about costs is the quality of services offered with the accounts. With government-organized accounts, the central question for this element is what Congress might legislate, and, underlying that, what services are likely to be requested by constituents. With privately-organized accounts, Congress will legislate a minimum standard of quality of services, but the market is likely to offer an array of services, extending above the minimum. In turn, this equilibrium is likely to be influenced by the details of the regulations that are placed on these accounts, for these accounts are likely to be subject to a new set of regulations, possibly administered by a new regulatory body or possibly handled by one or more existing bodies such as the SEC. These regulations will affect the costs of providing services and may include regulation directly of charges, either in level or in form.

There are many steps in organizing and running individual accounts. The costs of different steps might be paid by different sources: workers, employers, charges against the accounts, the rest of social security, the nonSocial security portion of the federal budget. In comparing different cost estimates, it is important to be clear about which tasks, and their costs, are included in a given estimate and which are assumed to be borne elsewhere. To help with such comparisons, the NASI Panel on Privatization of Social Security prepared a list of many of the tasks associated with having accounts in its Report. That list is reproduced here as Appendix A.

The paper proceeds by first describing how a low cost/low services government organized plan might look, how it differs from the Thrift Savings Plan for federal employees (TSP), and what it might cost. For this purpose I rely heavily on NASI, 1998. My estimate of the cost of such a system is roughly the range $\$ 40-50$ per worker per year. I suspect there would be pressure for more services, which would raise costs. After this discussion,

3 The paper does not consider the use of employers to organize groups for some workers as would follow with a mandate on employers rather than on workers. The Australian system is a mandate on employers. See, e. g., Edey and Simon, 1998 .

\section{December 16, 1998}


the paper turns to privately-organized accounts and the nature of equilibrium. My conclusion is that for the small accounts that are the current focus of political discussion (financed from 2 to 3 percent of payroll), the costs of private organization would be very high compared to the cost of government organization, given the perceived advantages of such a system.

\section{Government-Organized Accounts ${ }^{4}$}

The creation of mandatory government-organized individual accounts would involve setting up nearly 150 million individual accounts, with a system to produce a flow of deposits into the accounts and a mechanism for investing, reporting (and changing) portfolio choices. ${ }^{5}$ To put the scope of a possible new system in perspective, the TSP maintains fewer than 3 million individual accounts; the largest number of existing individual accounts handled by a single firm has under 6 million accounts; and there are fewer than 10 million IRA's with multiple investment options. No existing system could handle the administrative complexities of a program with this scope of individual accounts; creating one would take time and resources.

In addition to needing a structure for accumulation in individual accounts, a structure is needed for the provision of retirement income flows. This issue is considered below after considering the structure and cost of the accumulation phase.

Since the present structure of Social Security would be preserved for the remaining defined benefit retirement system as well as disability insurance and survivors' insurance for young families, any introduction of individual accounts would add to the costs of Social Security. Currently, Social Security costs about $\$ 16$ per person (workers and beneficiaries) per year. Excluding the costs of the disability program, OASI costs about $\$ 10$ per person per year. A cost of $\$ 10$ per participant is a cost of $\$ 14.50$ per worker. ${ }^{6}$

4 As mentioned above, much of the presentation of this section is verbatim from NASI, 1998 .

5 One can have a defined contribution system without any individual portfolio choice. While such a construct is useful for analytical purposes (see, e. g., Diamond, 1998), this is not on the agenda of proposals being taken seriously currently.

6 The estimate for is based on 1997 administrative cost of \$3.4 billion for the total program divided by 198.7 million participants (145 million workers and 43.7 million beneficiaries). The cost for only the retirement and survivors part of Social Security is based on administrative cost of $\$ 2.1$

December 16, 1998 


\section{I-A. Measuring costs .}

Setting up and administering a system of individual accounts involves a variety of types of costs. Some would be one-time costs to set up the system, independent of the size of the system. Other setup costs would depend on the number of participants. In terms of ongoing costs, most are fixed costs per account, while some depend on the size of the account. Since the bulk of ongoing costs would likely be fixed costs per account, estimating costs is approached in those terms (for example, $x$ dollars per account per year). That is, the cost of managing the aggregate portfolio is small relative to the costs of record-keeping, including communication with account owners. With the TSP, investment management fees are roughly 1/10th of total costs borne by TSP (with the costs borne by federal agencies also fixed costs per account). Dividing an annual dollar cost by annual deposits converts this to a percentage front-load.

It is also useful to express these costs in other ways. One familiar method of stating costs is as an annual management fee in percentage terms (for example, y percent of the accumulated balance in the account per year). Once the size of the accounts has been estimated, a dollar cost per year and a percentage of balances per year can be related by calculations that equate the present discounted value of costs over the career of a worker. If charges are imposed to cover the costs under these two methods, the charges will be equal on a lifetime basis, but will likely differ in any given year or stage of life. With balances that grow relative to wages, a constant percentage of balances is a smaller charge in early years and a larger charge in later years. A third way to report on the costs is in terms of the percentage decrease in the accumulation in an account at retirement age as a consequence of the administrative charges, called the charge ratio. The relationships among percentage front-load, annual management fee and charge ratio, based on continuous time calculations, are presented in Appendix B, which is reproduced from Diamond, 1998. Some examples are shown in Table 1.

billion and 182.6 million participants (145 million workers and 37.6 million beneficiaries) (Board of Trustees, 1998, p.97 and 105; and Statistical Supplement to the Social Security Bulletin, 1997, p. 167 and 183).

December 16, 1998 
Table 1. -- Decline in Value of Accounts Due to Fees After a 40-Year Work Career a

\begin{tabular}{|c|c|}
\hline Type and level of fees & $\begin{array}{l}\text { Percentage decline in } \\
\text { account value due to } \\
\text { fees }\end{array}$ \\
\hline Front-load fees (percent & new contributions) of: \\
\hline 1 percent & $1 \%$ \\
\hline 10 percent & $10 \div$ \\
\hline 20 percent & $20 \div$ \\
\hline \multicolumn{2}{|c|}{$\begin{array}{l}\text { Annual management fees (percent of account } \\
\text { balance) of: }\end{array}$} \\
\hline 0.1 percent & $2.2 \%$ \\
\hline 0.5 percent & $10.5 \%$ \\
\hline 1.0 percent & $19.6 \%$ \\
\hline
\end{tabular}

a. Assuming real wage growth of 2.1 percent and a real annual return on investments of 4 percent. With a larger difference between the rate of return and the wage growth rate, the charge ratio with annual management fees is slightly larger, and conversely.

The costs of organizing the accounts depend on the level of services provided with the accounts. Examples of variation in the level of services include variations in the frequency of deposits of withheld funds into the accounts, the number of alternative investment options available, the frequency of interfund transfers that are allowed, the frequency of reporting on balances, the availability of information (e. 9. , an 800 number), the ease of communication (e. g., the presence of people who can speak different languages), the amount of education made available to workers.

We begin by considering government-organized accounts that ha ve
relatively low costs and provide a relatively low level of services. The
following description is taken from the NASI Panel Report, with a few
modifications. In particular, using round numbers and reflecting diverse

December 16, 1998 
opinions, the Panel described a range of costs as being $\$ 25-50$. I use a range of \$40-50, because I consider this range more plausibly centered.

\section{I-B. An Illustrative Low-Cost/Low-Services Plan}

Transmission of funds. At present, employers pay Social security taxes to the Treasury shortly after each pay period, with a frequency depending on the size of the employer. However, these payments are not individually identified to the Treasury; that is, the Treasury knows the employer but not the individual employee associated with any tax payment. Once a year, employers file W-2 forms that show the annual taxable earnings of individual workers, which are needed for the eventual determination of benefits. Until 1978, firms reported on individual earnings quarterly, but that frequency was reduced to hold down costs, particularly for employers with few workers. ${ }^{7}$ At present, of the 6.5 million employers that report to the Social Security Administration each year, 5.4 million file their $\mathrm{W}-2$ reports on paper; these include more than $4 \mathrm{million}$ employers with 10 or fewer employees.

While shifting to more frequent reporting might not be costly for employers with electronic record keeping, doing so would represent a significant cost for small businesses. Therefore, in the low-cost /lowservices version of individual accounts, it is assumed that these taxpaying and reporting practices of private firms would not change. With this structure, the Treasury could place the portion of aggregate payroll tax revenues that was allocated for individual accounts in a separate trust fund, which would earn interest. Such a fund could hold Treasury debt, but it might be better to hold the estimated average portfolio, based on existing allocations and previous earnings. This would permit an allocation to individual accounts that reflected individual portfolio choices (which would have been made before the year began). Moreover, the allocation to individual accounts might go more smoothly in the capital market if assets were allocated to the accounts rather than funds to buy assets. Without a direct adjustment, there would be some difference between the total investment returns of the separate trust fund and the amounts to be credited to individual accounts. This difference could be averaged over time, or allocations could be adjusted each year, but something would need to be done. However, the allocation could not recognize the actual timing of payments by different workers; all workers would be treated as if the

7 Olsen and Salisbury, 1998, cite a 1972 estimate of the cost savings to small employers from dropping quarterly reporting which, "adjusted to 1997 dollars, ... would amount to about \$900 million a year."

December 16, 1998 
timing of their withheld tax payments were the same as the timing of aggregate withholdings.

Once a year, the Treasury would allocate the accumulated separate trust fund to individual accounts. To process almost all of the accounts without greater cost than at present would probably require 7 to 9 months after the end of the year in which the taxes had been collected. ${ }^{8}$ More time would be required for those cases in which there was a mismatch between the reported $\mathrm{W}-2$ information and Social Security records, as well as for the self-employed, who can file as late as April 15 (and later if they file for an extension). In a system this large, even a small percentage of errors adds up to large number of errors. Currently, roughly 3 percent of $\mathrm{W}-2$ forms (6 million cases) require direct contact with employer or employee to match the $\mathrm{W}-2$ and social security records. With the additional element of portfolio allocation, more errors would have to be resolved.

Portfolio choice. Under this structure, individuals would inform Social Security about the division of their deposits among the available portfolios. Workers might do this directly or through their employers, but in either case it would have to be done before the start of the calendar year, with the allocation unchanged from the previous year unless the worker requested otherwise. Presumably a chosen allocation would be unchanged until a worker selected a different one. Thus a worker changing employers would not need to report a portfolio choice to social Security; only newly covered workers and workers wanting to change their allocations would need to report. Since many new and changed allocations would be reported on paper if done by a firm or on paper or by phone if done by workers, there are likely to be errors and a need for both an error correction mechanism and a record-keeping function to provide evidence for sorting out errors afterwards. 9 Some individuals, particularly newly covered workers, would not have selected an allocation, and there would have to be a default portfolio for these workers. This could be legislated to be similar to the current portfolio of the Social security Trust Fund, or the average portfolio in individual accounts, or a prudently selected portfolio. In addition to directing the flow of new deposits among different index funds, workers would be allowed to shift existing account balances on a limited basis,

8 Mitchell (1998) reports that "only 70 percent of earnings were posted within six months of the tax-year end in 1991."

9 As an example of the difficulties present in error correction, Olsen and Salisbury (1998) cite unpublished SSA data (1998) that "approximately 10 percent of employers reporting wages to SSA go out of business each year."

\section{December 16, 1998}


such as once a year. Again the mechanism for allowing this would need a record-keeping mechanism to deal with possible mistakes or claims of mistakes. Similarly, information on the level of their accounts would be provided directly to workers only once a year. Workers could infer the value of their accounts by knowing the number of units held in each account and checking the values of those units, which would likely be presented regularly in the media.

To keep costs low, worker education about portfolio choices would be limited to providing pamphlets on investment strategy. It should be noted, however, that experience with worker education in $401(\mathrm{k})$ plans shows that considerably more substantial (and expensive) worker education is needed to have a noticeable effect on workers' investment choices (Bayer, Bernheim, and Scholz, 1996). Moreover, the covered population includes many people who have not considered investment choices, making this low level of education an important issue. As reported by Arthur Levitt (1998), SEC research indicates that half the public do not know the difference between a stock and a bond. In addition to this minimal outreach providing education, Social security would need to respond to questions asked by covered workers. Presumably this would be a major source of cost, particularly reflecting the education and language difficulties of part of the population.

Handling and managing the aggregate funds would probably require only a small management fee. Currently, the TSP is charged roughly 1 basis point by the fund managers handling the bond and stock funds.

Benefits. The cost of paying retirement benefits from individual accounts must also be considered. Assuming annuitization were mandated, the least-cost approach would be automatic annuitization of these funds according to rules set by legislation, with the payments added to the payment of whatever defined benefits were maintained. Information would be provided to beneficiaries on the source of each payment.

\section{I-C. Cost}

A starting place for estimating the additional costs to social Security for adding such a low cost/low services individual account plan is the portion of the costs of the TSP that fall on the TSP (that is, excluding the costs that fall on federal agencies that educate workers, answer questions and report earnings records to the TSP and excluding the administrative costs coming from the payment of annuities (which are paid by retirees and reflected in the price of privately supplied annuities). The TSP cost is currently roughly $\$ 20$ per

\section{December 16, 1998}


worker per year, although the costs were lower when fewer services were provided. ${ }^{10}$ With 140 million accounts, a cost of $\$ 20$ per worker would be an aggregate cost of $\$ 2.8$ billion per year. The startup costs of TSP in 1987 were $\$ 5.25$ milion; if the startup costs were the same per participant, the 1998 cost would be $\$ 1.08$ billion (Olsen and Salisbury, 1998).

There are a number of issues involved in comparing TSP costs with the incremental costs of the low-cost/low-services system just described. On the one hand, the TSP provides better services (in frequency of reporting, frequency of portfolio change, and frequency of deposit), must deal with loans against workers' accounts, and has fewer economies of scale. In addition, Social Security would have some economies of scope. For example, a single annual statement can contain information on both parts of the system. These factors tend to lower the costs of Social security individual accounts relative to TSP costs. On the other hand, there are factors that tend to raise the cost of Social security individual accounts relative to TSP costs. First, many costs of the TSP system are borne by federal agencies as employers. They handle the education of participants (providing more education than described in the low cost plan), respond to their questions, enroll them in the plan, transmit their portfolio choices electronically, and make employees whole when reporting errors cause them to lose investment returns on their contributions. If employers do not fill the roles they fill with the TSP, these costs will likely fall on Social Security. Many of the 140 million workers have more limited education and less proficiency in English than is typical of federal employees, and direct contact would be needed to handle the tasks above. For example, providing account information over the internet costs 1 percent of the cost of providing the information by an operator responding to an 800 number and 4 percent of the cost of providing it by an automated 800 number (Dickson, 1998). The Social Security population would make less use of the internet, on average, than the $401(\mathrm{k})$ population. Second, Social security covers many small employers that report social security records on paper, rather than electronically, which would add to the cost and risk of errors in record keeping. While error correction for earnings needs to be done for the continuing defined benefit system, adjusting individual accounts for the same errors would be an additional cost. Also correction of errors in reported portfolio choice would have additional costs. Third, Social Security covers part-time, intermittent, and highly mobile workers, many of whom have multiple

The estimate for TSP is based on its 1997 balance sheet and includes : administrative costs of $\$ 44.1$ million; investment management fees of $\$ 2.3$ million; and fiduciary insurance of $\$ 0.2$ million, divided by 2.3 million participants (Arthur Anderson LLP, 1998).

\section{December 16, 1998}


employers, whereas federal employees have low labor mobility. Fourth, there are likely to be mandatory adjustments upon divorce, and/or account sharing between spouses. Finally, there will be costs of providing benefits, whether annuitized or paid out regularly, which are not part of TSP costs. A range of \$40-\$50 per worker per year seems to me a reasonable rough order of magnitude for a low cost/low services plan. A bit lower or somewhat higher can not be ruled out. I note that this is a considerably higher cost than the 10.5 basis points for accounts financed by 1.6 percent of payroll assumed by the Advisory Council (1997).

While the bulk of the costs would be fixed per account, their effect on the accumulation in individual accounts would depend on how charges for these costs were allocated across accounts of different sizes. The charges could be proportional to deposits or to account sizes, implying that all workers with the same portfolio choice would receive the same rate of return. Alternatively, the charges could include a fixed component reflecting the underlying structure of the costs, implying that workers with higher accumulations would have better rates of return net of charges. The importance of this choice depends on the dispersion in earnings for the covered population. In 1996, 22 percent of workers covered by Social security earned less than $\$ 5,000$, while 58 percent earned below $\$ 20,000$ (Table 2). Presumably, government-organized accounts would follow the approach of uniform percentage charges.

How would these added costs affect the retirement income of covered workers? The relative significance of a cost range of $\$ 40-\$ 50$ per worker per year would depend on the proportion of workers' earnings being deposited in the accounts and the size of their earnings. In 1997, mean Social Security taxable earnings were approximately $\$ 23,000$. If 2 percent of workers' earnings went to individual accounts, the mean deposit would be $\$ 460$. A $\$ 40-\$ 50$ cost charged to the account would be equal to 9-11 percent of the new contribution (equivalent to a ?front load? charge) for the mean earner. Presumably the cost would rise roughly in step with average wages, keeping the front load roughly constant in percentage terms. These calculations would be the same for workers at any earnings level if charges were the same percentage for all workers. If charges reflected some of the fixed costs of accounts, the load would be larger for low earners and smaller for high earners. The calculation for accounts financed from larger or smaller percentages of payroll would be proportional.

Another way to describe these charges is to ask what charge as a fraction of assets under management would cover these costs on a lifetime basis,

\section{December 16, 1998}


assuming that the cost grew with average wages. Using Table 1, with 2 percent accounts an annual $\$ 40-\$ 50$ change would be roughly equivalent to a 40-50 basis point charge on assets under management over a 40-year career.

We note that the distribution of earning of workers covered by social Security is very different from that of earnings of current $401(\mathrm{k})$ participants. In contrast to Table 2, of workers participating in $401(\mathrm{k}) \mathrm{plans}$ in 1993, only about 20 percent earned less than \$20,000 (EBRI, 1994).

Table 2. Percent of Workers with Social Security Earnings Below Specified Levels

Wage and Salary Workers, 1996

\begin{tabular}{|c|c|c|}
\hline \multicolumn{2}{|c|}{ Workers } & \multirow{2}{*}{$\begin{array}{c}\text { with annual } \\
\text { taxable earnings } \\
\text { of less than: }\end{array}$} \\
\hline Number & Percent & \\
\hline 29,554 & 22 & $\$ 5,000$ \\
\hline 46,438 & 35 & 10,000 \\
\hline 61,816 & 46 & 15,000 \\
\hline 76,178 & 58 & 20,000 \\
\hline 88,900 & 67 & 25,000 \\
\hline 99,458 & 73 & 30,000 \\
\hline 114,629 & 85 & 40,000 \\
\hline 123,641 & 91 & 50,000 \\
\hline 128,591 & 95 & 60,000 \\
\hline 129,578 & 96 & 63,000 \\
\hline 136,689 & 100 & 63,001 \\
\hline
\end{tabular}

Source: Office of the Actuary, SSA.

\section{I-D. Level of Services}

December 16, 1998 
Costs would be raised by the provision of additional services, such as more frequent reporting on accounts, more frequent deposits into accounts, more frequently allowed reallocations of existing portfolios, more readily available information on account balance, more resources devoted to answering questions, or more worker education. Thus a critical question is what level of services would be a political equilibrium. A low cost/low services plan would provide far fewer services than a typical $401(\mathrm{k})$ account with which much of the public is familiar. That might be one source of pressure for more services. In addition, unless voters make a good connection between services and costs, there might be pressure for more services which Congress might be prone to satisfy since Congress does not have to legislate a tax increase to finance the higher services, the higher cost just coming out of the individual accounts without explicit pricing by Congress. Thus a steady rise in services and costs might well be the political equilibrium, as it has been with the TSP.

\section{I-E. Payment of benefits}

The cost of paying retirement benefits from individual accounts also depends on legislative decisions. Assuming annuitization were mandated, the least-cost approach would be automatic annuitization of these funds according to rules set by legislation, with the payments added to the payment of whatever defined benefits were maintained. Information would be provided to beneficiaries on the source of each payment. Such a system would add little to the cost total costs of Social security. However, this method for providing services might not be the political equilibrium. An important issue with mandated annuitization of accounts that are individually owned and managed is the political stability of such a proposal as the public's view of Social security shifts. For example, would an individual with limited life expectancy or extraordinary immediate needs be forced to annuitize? Indeed, proposals for individual accounts sometimes propose alternatives, including some degree of choice as to how benefits are received. Another reason why this might not be the political equilibrium is that it would involve social security's directly holding the assets that back the annuity promise. Some of the reasons some people favor individual accounts have them favoring private market provision of annuities, unless the backing is fully in indexed Treasury debt. First, we consider private market provided annuities for government-organized accounts with mandated annuitization. Then we consider possible alternatives for benefit provision.

\section{December 16, 1998}


Annuity provision. Annuitization of individual accounts might be accomplished in three different ways. First, the federal government could decide what benefits to pay for given accumulations, with social security bearing the risk inherent in projecting mortality and selecting a portfolio. Second, the federal government could contract with private providers to receive accounts from the government in return for paying the annuities. These annuities would be priced on a group basis. These payments could go directly to beneficiaries or to the government for transmittal to beneficiaries; in the latter case, the government would provide the payments directly to beneficiaries along with defined benefits. The private providers would bear the mortality and return risks, although there would be residual risk that a private insurance company would be unable to meet its obligations for annuity payments. It would be undesirable and probably politically untenable to put that residual risk on individuals, particularly those late in life. Therefore, the government should absorb that residual risk. Currently, insurance companies receive oversight from state governments, not the federal government; with such a residual risk for the federal government, there would be a call for federal oversight instead of or in addition to state oversight. Third, individuals could be left free to contract with insurance companies on their own, purchasing annuities from their accounts. This approach would employ individual rather than group purchase of annuities. In insurance markets generally, group products are considerably less expensive than individual products. This outcome reflects both lower costs for insurance companies in dealing with groups and greater competition for large group accounts than for smaller individual accounts. Costs with the third approach would be considerably higher than with either of the other two. The costs of private market annuitization are discussed elsewhere at this conference (Poterba and Warshawsky, 1998); see also Mitchell, Poterba, Warshawsky and Brown, (forthcoming).

Like many insurance products, annuities are offered far more cheaply on a group basis than on an individual basis. In order to have private provision on a group basis with a large national program some mechanism would be needed. One issue is the sheer size of the program, calling for the use of multiple groups and multiple providers, rather than a single provider of annuities for all retirees. If multiple groups are used, then, to preserve as much of the advantage of groups purchase as possible, the government needs to allocate people to different groups, rather than allowing the market to form the groups (Diamond, 1992). Since there is little reason for a geographic concentration of benefit recipients, people could be allocated to different groups randomly, giving everyone roughly the same opportunities,

\section{December 16, 1998}


which could be adjusted by cross-subsidization between groups receiving slightly different bids. While such group provision is likely to be somewhat more expensive than government provision provided the same portfolio were held for backing for the annuity promises, there is probably not a great deal of difference in cost. What is likely to be more of an issue is the determination of benefits. With private provision, the political outcome is more likely to be to accept the prices offered by the market. With government provision, there may be pressures for intervention when the pricing implied by mortality projection and current interest rates involves a drop in benefits.

Benefit alternatives. Proposals take three different forms with regard to allowing choice about retirement income. Some proposals allow lump-sum withdrawals, leaving the worker free to choose the extent of annuitization of that portion, whatever rules apply to the remaining balances. While providing a lump sum is not expensive to social security, retirees who do want to annuitize are then left with the private annuities market in which to annuitize. Private-market annuitization on an individual basis is considerably more expensive than is provision of retirement benefits by Social Security, making this option costly for those who might annuitize. Those who did not annuitize would be bearing the risk of outliving their retirement wealth. An intermediate position is to give workers a choice between annuitization and periodic withdrawal (monthly, for example), with a limit on the size of the allowed withdrawal to limit the risk of outliving the retirement wealth. Other proposals mandate annuitization of the entire accumulation. An important issue with mandated annuitization of accounts that are individually owned and managed is the political stability of such a proposal as the public's view of social security shifts. For example, would an individual with limited life expectancy or extraordinary immediate needs be forced to annuitize? Moreover, with mandated annuitization, the issue remains of the extent to which any mandate is for inflation-adjusted annuities and/or for joint and survivor annuities for married couples.

I-F. Conclusion. While individual accounts and annuitized benefits could be provided at a cost of around \$40-50 per year, a critical question is what the political equilibria would be for the level of services during accumulation and for the structure of benefit provision after retirement. Cost estimates need to recognize the uncertainty in what will be legislated for the accounts.

\section{Privately organized accounts}

December 16, 1998 
To consider the charges for government-organi zed accounts, we followed three steps. First we described a level of services that is a candidate to be provided if there are government-organized accounts. Second, we estimated costs for that plan, noting that additional services increase costs. And third, we suggested that the costs would be allocated to different workers in proportion to either deposits or account balances, or some combination. To consider privately-organized accounts we discuss the level of services that might be provided and how the costs differ from those with governmentorganized accounts. In addition, we need to consider the issues raised by competition among private firms. In doing this, we shall keep in mind a realistic picture of competitive markets, not an idealized one. Charges differ from the costs identified because of marketing costs and markups (which interact in equilibrium).

\section{II-A. Deposit of funds.}

There are three methods of deposit of funds to consider. In parallel to the low cost/low services government-organized plan described above, we consider a system where the government continues to collect all of taxes and transmits them once a year to private financial firms, with workers directly informing the government as to which private firm to use. Second, we consider having employers directly transmit the funds to financial firms. Third, we consider direct deposit by workers, keying off a tax credit. We need to keep in mind costs that fall on all three players in this scenario workers, employers, and government.

If the government transmits the funds once a year to firms, then there are some additional costs for government beyond having the government transmit the funds to itself. The actual transmission is not likely to have significant costs, but there are additional steps. Workers must inform the government as to the destination of the funds. There is a major design issue at this stage. Is a worker restricted to keeping his or her account at a single financial institution or are workers allowed to have accounts at several institutions? If it is the former (as in chile) then the government needs to enforce this consistency. When a worker, particularly a worker with a new employer, selects a financial institution, the government needs to check for consistency with the location of the existing account. With a centralized deposit plan this is readily doable. Without a centralized system, restricting workers to a single account is probably not feasible and we would have, as in Australia, a problem of many very small accounts,

\section{December 16, 1998}


particularly as some low earners might start many accounts. This will be a problem for the workers who start multiple accounts in the absence of regulatory restrictions and/or subsidies since the earnings on small accounts would not cover the costs of maintaining them. If firms are required to charge all accounts the same percentage amounts (and to accept all workers), this cross-subsidization of multiple accounts is part of the cost for everyone. In Australia, this is a significant problem and is one reason for preferring centralized transmission of funds. We assume that workers are restricted to a single account each. Otherwise costs per account need to be multiplied by accounts per worker to estimate costs per worker.

With government transmission of funds, the costs include verifying and correcting mistakes in the choice of firm, verifying and correcting mistakes on the deposits in financial firms (e. g., do the social security number and name in the firm's records match those of the incoming deposit information), and overseeing transfers between firms. It seems plausible that many workers would shift financial firms from time to time. In Chile, turnover is roughly 20 percent per year. Transmission would not cost much since all communication between government and firms would be electronic and would be likely to be accurate. The problems would come from the errors at either end.

Direct deposits from employers would be significantly more expensive for both employers and financial firms. Financial firms would have to process many paper transactions (duplicating the same paper transactions being handled by SSA) and would have to deal with many employers separately. Similarly, employers would have higher costs, whatever the frequency of transactions, from dealing with many financial firms as well as with government. In Chile there are a small number of AFPs so the process is not so bad. In the US there would be a vast array. While there would arise private clearing house arrangements (which have not arisen in chile) to help particularly small firms, this is another layer of costs and markups. Moreover there would be the usual tensions in a naturally increasing-returns activity between costs and competitive pressures depending on how many firms survived as clearing houses. Financial firms would still have the problem of communicating with both workers and fund transmitter (employers rather than government) which adds to costs. Since this seems to add significantly to costs and has little in the way of benefits that are apparent to me in the US context, I will not consider such transmissions further. While there would be some economies of scope from combining these accounts with $401(\mathrm{k}) \mathrm{s}$, it is important to recognize that only a fraction of workers have $401(\mathrm{k}) \mathrm{s}$, that

\section{December 16, 1998}


regulations covering $401(\mathrm{k}) \mathrm{s}$ are likely to be different from those covering mandated accounts (requiring separate record-keeping), and that it is unlikely that workers would be required to use only the options provided by the employer that provides their $401(\mathrm{k}) \mathrm{s}$. So while there is an advantage here, it is unlikely to offset the sizable cost disadvantage of this approach.

Direct deposit by individual workers has the advantage for financial firms that the firms are only dealing with a single entity, although they would still need to keep the government informed, as with mutual funds currently. The agent with whom they must communicate anyway is the one making the deposit and with the job of checking that the deposit is properly handled. With many workers without financial sophistication, the government is likely to play a larger role in policing accuracy than is true for dealing with voluntary accounts with financial firms currently. This would follow from both the difference in populations from those currently dealing with financial firms handling retirement savings and from the presence of a mandate. In addition, deposits would be overwhelmingly on paper, making for considerably higher costs and error rates than with a single electronic transmission from the government. This seems to me likely to be noticeably more expensive than government deposit. Moreover, it involves issues of some workers filing for refundable tax credits who would not otherwise file taxes. So I will do the analysis based on government collection of taxes and transmission to private firms.

\section{II-B. Alternative investments.}

One of the major arguments in favor of privately-organized accounts is the presence of a wider choice of investment options. In particular, one would expect that all three of the banking, insurance, and mutual fund industries would be active participants in this market. Banks would offer CDs and a vast array of locations. Insurance companies would offer accounts with insurance features attached to them. Mutual funds would offer managed as well as indexed funds, and possibly individually designed portfolios.

Several issues arise from this array. One is the currently diverse regulation of these different institutions. In particular, mutual funds and banks have different federal regulatory agencies while insurance companies are regulated at the state level. Presumably this would change in a significant way if we had privately-organized accounts.

December 16, 1998 
A second major issue is how to think about the value of this diversity, as well as the increased diversity just within mutual funds. As economists, we normally consider increased options to be advantageous, provided that the increased options do not come with adverse price changes as part of adjustment to a new equilibrium. This need not be the case here for two reasons, both related to the purpose of and motivation for social security. First, the purpose is to have retirement income. Insofar as workers (implicitly) trade off current services (including possibly kickbacks) for a lower rate of return (and so lower retirement incomes), the increase in options in privately-organized accounts are cutting against the primary purpose of the mandate. Second, insofar as the mandate comes from a concern that individuals do not do a good job of looking out for themselves when it comes to retirement planning, it seems right to recognize that many people will not do a good job of choosing a financial intermediary for retirement savings as well. The current financial market is marked, as are almost all retail markets, by a diversity of prices for similar, sometimes seemingly identical products. Some people end up with high cost options. Since individual accounts would be an ongoing relationship, with little at stake in any particular month, workers, particularly low earners, would not have much incentive to stay on top of the changing array of alternative investments and alternative charges. In the absence of detailed regulations limiting pricing alternatives, we might see a dizzying array of prices and arrangements in this market.

In this setting, it is important to move beyond an "average" worker and to recognize the allocation of workers across different options and the relationship between different worker characteristics, particularly earnings level and options selected. Thus it would not be an adequate analytical approach to consider the availability of some low-cost option as the basis for evaluation, with an assumption that everyone choosing some higher cost option is gaining from making that choice. Both positive political economy and normative considerations suggest that this would be a tightly regulated market, with both the benefits and costs of tight regulation.

Comparing costs. In some settings, private firms have lower cost functions than the government because they have access to better technologies, are able to generate better incentives for workers or can pay lower wages, perhaps by avoiding unionization. The potential for these opportunities depends on the nature of the task being fulfilled. As Wilson (1989) has argued, some bureaucratic tasks have outputs that are easy to measure and so it is easier for a government bureaucracy do a good job. Current social security is in

\section{December 16, 1998}


this category. The tasks are well defined (collect money, keep records, distribute money, provide information). Indeed the costs of social security are very low compared to private firms doing similar activities. Moreover this is not a special US outcome, but a common feature of many national pension systems in advanced countries. (On costs in other advanced countries, see Mitchell, 1998.) It seems to me that organizing a TSP type system has similar characteristics from the perspective of ease of bureaucratic management. I would not expect private firms to have lower cost functions than the federal government. In addition to considering the cost functions, there are issues of returns to scale, since the government system would be vastly larger than the average private system. While some firms may have economies of scope from combining their share of social security individual accounts with other fund management activities, social security has economies of scope as well. I conclude by suggesting that record-keeping and investment management costs are likely to be higher with privatelyorganized than with government-organized accounts.

Charges. If the world were like an idealized competitive market, then all we would need to know is costs, since charges would equal costs, in the absence of regulation. But observation of other countries that have national (mandated or voluntary) privately-organized individual accounts (Chile, Argentina, UK) makes it clear that this model does not apply. Similarly, consideration of voluntary individual capital market in the US shows considerable advertising expenses and charges that do not have the structure of costs.

There are two aspects to thinking about equilibrium in such a market. What will be the structure of charges and what will be the levels of pricing parameters in the structure. Currently, the most common bases for charges in mutual funds is proportional to the amount in an account or a combination of the amount in an account and the amounts being deposited - in 1997, 1oad funds accounted for more than half of all new sales of equity funds (Rea and Reid, 1997). The market has higher charges for people with lower accounts, minimum account balances, and some flat charges. It is plausible that, without regulations on the structure of charges, mandatory accounts would see a similar structure. I am not aware of analyses as to why this structure has evolved. I suspect that a charge in basis points is less psychologically aversive than one in dollars - it is harder to think about how much it actually is costing. Since the advantage of having "better" management of funds increases with the size of the funds, charges that vary in this way may take advantage of the way charges will be viewed and the extent to which

\section{December 16, 1998}


investors will shop and switch. Presumably this is a market with considerable inertia as to switching, even though switching costs are very low (except from firms that have back loads or to firms that have front loads on transfers).

Looking across different portfolios, it does seem to be the case that those funds with higher costs have higher charges, but there is considerable spread in charges within portfolio categories, indeed even within index fund categories that are tracking the same index. Spreads in prices for the same services are widespread phenomena in retail markets, and suggestive of imperfections in perceiving and acting on alternatives that exist in the market. This suggests that, without regulation to the contrary, charges on average will be higher (in percentage terms) for accounts which are financed with a smaller fraction of taxable payroll. It also suggests that charges on average will be higher (in percentage terms) for lower earners than higher earners.

This view of markets as having markups and variation primarily because of consumer lethargy is clearly different from a perspective that consumers are choosing the best option in an array of competitive firms that offer different qualities of services at different prices. It is the case that firms offer different services in terms of the nonreturn aspects of services. But I find it hard to accept the competitive market model. This would be particularly an issue with mandatory accounts where people may not know how services vary across firms nor how to value such services. In particular, it is very difficult to assess whether some portfolio managers are better than other portfolio managers, even if one understands the concept of a riskreturn tradeoff. Given the difficulty in doing this with sophisticated analysis, most workers would have considerably greater difficulty, even though Consumer Reports would be giving ratings to the small fraction of the public that would follow such information. I conclude that equilibrium is likely to have substantial markups, together with the selling costs that are encouraged by such markups.

This possibility has led some analysts to call for a cap on allowable charges for handling privately-organized accounts. Our experience with regulation of prices leaves it unclear how well such regulation would work. In addition, caps would be somewhat difficult to enforce. Some types of accounts (e. g., CD's) do not have separate charges. Currently charges from brokerage fees are treated separately from other charges. And costs are

\section{December 16, 1998}


different for different types of accounts (bond vs. stock, domestic vs. international, index vs. managed).

Current examples. One approach is to consider existing market alternatives and their costs. While this might give some idea on average charges, it is more difficult to consider the degree of matching of different workers with different institutions. It also needs to be recognized that the average size of accounts may well be different from any particular example and that the population whose demand reactions affect pricing would be different.

A key point is that individuals will be seeking out firms on an individual basis. Thus quotations of charges made by financial firms on an institutional basis, while relevant when considering costs with governmentorganized accounts, seem to me irrelevant when considering privatelyorganized accounts. We therefore need to consider the market for individual choice or the market that deals with small firms. It is natural to look at 4 pieces of evidence. What has happened in other national systems with individual accounts organized individually. What are charges for mutual funds and other investment vehicles? What are charges with IRAs and 401 (k) s? It is also important to look at the entire market and not just the offerings of one or a few firms. Since other papers in this volume also consider the available information, I will be brief.

Costs in Chile (which are front-load costs of roughly $15-20$ percent) are roughly equivalent to 75-100 basis points on accounts that are 10 percent of taxable wages (which seems to me relevant since the labor costs of the financial firms will resemble the average labor costs in an economy). Argentina, with smaller accounts, has larger charges. Mexico, which has amounts put in the accounts by the government as well as amounts withheld from workers have higher charges relative to the deposits of workers' withholding, but lower charges relative to total deposits. UK has considerably higher charges than Chile. ${ }^{11}$

Some people have argued that costs are high in chile because of the nature of regulation. Regulations require uniform pricing for all workers, preventing the formation of groups that might bargain for lower prices, with an unclear implication for charges to the remaining population. Regulation on the structure of charges (only frontloads and only a combination of flat and proportional charges) would not prevent competitive pressures, if they

11 For more details, see Diamond, 1998.

December 16, 1998 
are as in the idealized market, from keeping charges, on average, close to costs, and so holding down the incentive for sales efforts. The high markups over production costs and high fraction of costs devoted to sales suggest that it is inherent in individually organized markets for this type of product to have high markups. The similarity of costs in chile to those in markets without such price-structure regulations also suggests that the details of the regulation are not the prime reason for the level of costs. 12

A recent ICI study of equity mutual funds (Rea and Reid, 1998) argues that the average dollar invested in individual funds in 1997 was charged around 149 basis points, not including any brokerage charges that go with many of these products. The calculation includes balanced and other hybrid funds. This calculation includes both annual maintenance charges and an annualization of front-load charges. ${ }^{13}$ The study also reports that this average charge has fallen from 225 basis points in 1980 . The study does not report the average size account, which would help for comparison with individual Social Security accounts. ${ }^{14}$

I do not know what the implicit charges would be with bank CDs. Similarly, I have not looked into insurance company charges.

I do not examine IRA and $401(\mathrm{k})$ charges - for discussions of the
literature, see Mitchell (1998) and Olsen and Salisbury (1998). As they
note, some data sources (e. g., Form 5500) only report part of the charges

12 Australia has a mandate on firms, not workers. Thus evidence from the large firm section of that economy do not seem relevant for the typical proposal in the US.

13 The study argues for the importance of including front-loads since roughly two-thirds of retail investors buy mutual funds through sources offering load funds, load funds accounted for more than half of all new sales of equity funds in 1997 and represented 60 percent of equity fund assets at the end of 1997. The study does not seem to deal with the complication in annualizing front loads from the fact that the interest rate relevant for the individual depends on the charging structure. I suspect this would not be a significant change in the calculation, but it should be examined.

14 Mitchell (1998) reports on expense ratios without front-loads separately for different types of mutual funds and does report on average account sizes. For fiscal years ending in 1994-95, calculations show expense ratios varying from .324 for equity index funds to 1.043 for growth funds and 1.250 for global funds. From average account sizes, these translate into $\$ 67.9$ for index funds and $\$ 137.5-302.5$ for the other funds.

December 16, 1998 
made by financial firms. We need to recognize that both IRA and voluntary accounts may well have lower costs than mandatory accounts because financial firms deal only with the depositor in these cases, but would deal with both the government and the individual with mandatory accounts. On the other hand, $401(\mathrm{k}) \mathrm{s}$ have considerable regulation for tax qualification and have financial firms deal with both employers and employees. Thus the costs for providing services to small firms may well be higher than with mandatory accounts organized with direct government deposits. Larger firms have economies of scale and bargaining power in negotiating individual deals rather than accepting a take-it-or-leave-it offer in the market - so their charges and costs are probably not relevant for thinking about privatelyorganized accounts.

I see no reason to think the nature of equilibrium with privatelyorganized individual accounts would be dramatically different from these examples. The accounts would be smaller and the population dealing with the financial community more diverse and less sophisticated on average. I suspect the costs for the typical worker choosing a mutual fund would be at least 100 basis points with accounts from a large percentage of payroll, and larger, possibly considerably larger, if we are considering accounts financed with only 2 percent of payroll. I note that this is roughly consistent with the 1 percent cost for accounts financed by 5 percent of payroll assumed by the Advisory Council (1997).

Implications of charges. For example, with 100 basis points of accumulations per year charged over a full career, and assuming the wage growth exceeds the interest rate by $2 \%$, the final accumulation in privately-organized accounts would be reduced by 19.6\%. Other examples were reported in the Table 1. Thus, privately-organized accounts are likely to deliver accumulations at retirement that are at least 10-15 percent lower than could be delivered by government-organized accounts, and quite possibly even lower. In addition, the provision of annuitization would be more difficult and would likely be more expensive.

II-C. Conclusion. My conclusion is that privately-organized individual accounts are very expensive for satisfying the basic purpose of social Security. Since I think that government-organized accounts can be reasonably insulated from political interference, that the increased choice that would be present with privately-organized accounts may be as likely to be harmful to the worker as helpful, and that greatly increased regulation is likely, with the uncertainties created by the introduction of a new regulatory

\section{December 16, 1998}


structure, I consider privately-organized accounts to be dominated by government-organized accounts.

December 16, 1998 
Appendix A

\section{Tasks in Implementing Individual Accounts}

This list first considers tasks in implementing government-organized accounts, and then notes tasks that would be different with privatelyorganized accounts.

\section{Government-Organized Accounts}

This list assumes that contributions are received throughout the year, and are linked to individual taxpayers after the end of the year, when $W-2 \mathrm{~s}$ are filed. It also assumes that the government receives the money, arranges for investment, recordkeeping and benefit payments. An asterisk (*) indicates tasks now done by the Social Security Administration or Treasury, or similar tasks. In some cases, the tasks become more complex because of differences in timing or other concerns.

\section{Collect Contributions from Employers}
a. Receive and record money from employers shortly after each payday . *
b. Reconcile amounts received with quarterly 941 and annual W-2 reports to detect missing or discrepant payments .*
c. Segregate account contributions from other taxes paid by employers.

2. Invest Funds
a. Select a private fund manager(s).
b. Invest new contributions during the year according to government policy.
c. Designate a default investment portfolio for individuals not selecting one.
d. Report investment returns to the recordkeeper - annual average for new contributions, monthly/quarterly for account balance valuations.

\section{Credit Workers' Accounts with New Contributions}
a.
Find missing or inconsistent reports from employers by reconciling annual and quarterly reports and correspond with employers to fix it.*
b. Record new contributions to individual accounts. Identify discrepancies between $\mathrm{W}-2 \mathrm{~s}$ and SSN files and correspond with employers or employees to fix mistakes.
c. Set up new information system of records needed to administer accounts: workers' ID, portfolio choice, effective date of choice, interfund transfers and date of interfund transfer, death beneficiary designation, marital status, spouse ID, and spousal consent code (depending on policy), current address.

December 16, 1998 


\section{Enroll Workers and Get Portfolio Choice (and Other New Information)}

Depends on employer involvement (either mandatory or voluntary). Options include: (i) ongoing requirement that employers enroll new employees and report portfolio choices annually (on W-2s or W-4s); (ii) one-time employer responsibility to enroll workers in the plan and send data to the record keeper; (iii) do not involve employers -- deal directly with workers through 1040s, correspondence, phone, website or in person.

\section{Educate and Communicate with Workers}

a.

b.
"Wholesale" tasks (such as in the TSP) include developing educational brochures, videos, training courses for employers to use to enroll workers.

"Retail" tasks (performed by employers in the TSP) include oneon-one communication with workers -- via Social security (or IRS?) field offices, an 800 number, website.

6. Pay Death Benefits

a. Determine policy for death benefits including registry of state laws on inheritance rights and rules for determining jurisdictions, if relevant.

b. Set rules of evidence for determining correct death beneficiary and maintain record system to support it.*

c. Resolve competing claims when they occur.*

\section{Implement Policy on Treatment of Accounts at Divorce}

Possible policies include: (i) let courts decide; (ii) automatically divide $50 / 50$ changes in account balances that occurred during the marriage; and (iii) automatically divide contributions each year between spouses. Depending on policy, tasks include:
a. Set policy for treatment of QDRO (qualified domestic relations order from court).
b. Maintain historical records that can be used to retroactively combine and split two individuals' change in account balances for a period of years or each year, link accounts of husbands and wives and transact a split.
c. Set up systems for verifying marital status and spouse ID, and policies for resolving disputes, discrepancies, and informing each party of transactions made on their accounts.

\section{Pay Retirement Benefits}
a.
Determine policies about nature of withdrawal options.
b.
With annuities, determine whether government or insurance companies will: (i) assume mortality and investment risk; and/or (ii) administer the annuities.
c. If insurance companies, determine policy for their involvement -- e.g., standards for participation, competitive bidding for group contract, some sort of reinsurance.
d. Policy on joint-and-survivor annuities and beneficiary designation for non-annuitized funds (or period certain annuities).

December 16, 1998 
9. Retirement Benefit Counseling (assuming a number of withdrawal options are available)

a. Explain to retirees what the choices are and what terms mean and run scenarios of how different choices would affect the particular retiree and spouse.

b. Set policies (if any) on who will provide the information and who will pay for it.

10. Early Access (if loans or withdrawals end up being allowed for "hardship.")

a. Determine hardship rules and how they will be applied.

b. If loans, set up systems for how they will be repaid.

\section{Privately-Organized Accounts: Additional Tasks}

This list assumes that funds are withheld and paid by employers to the government (as they are now) and that employers report annually on $\mathrm{w}-2 \mathrm{~s}$ the amounts belonging to each worker. The government's tasks in collecting contributions would be the same as in government organized accounts.

When $\mathrm{W}-2 \mathrm{~s}$ are in, the government would send each worker's funds to a financial institution chosen by the worker. The financial institution would be responsible for all further dealing with the account holder. It would be responsible for: investing funds, crediting workers accounts with new contributions, getting information about the worker's portfolio choice and other data needed to pay benefit to the worker or his/her beneficiaries, educate and communicate with workers about investment choices, pay death benefits, implement policy on treatment of divorce, pay retirement benefits under applicable rules, and provide retirement benefit counseling. It would also be responsible for enforcing whatever policy applies with regard to early access.

New issues and tasks that arise under this model:

a. Government would maintain a default plan or default institution for workers who fail to designate a financial institution.

b. Government would set rules on financial institutions eligible to hold Social security accounts.*

c. If workers would be required to hold their funds in only one institution at a time, government and financial institutions would put systems in place to ensure that happened.

d. Once money is sent to the financial institution, it would be responsible for receiving portfolio choices from workers, sorting out mistakes and making employees whole under whatever rules apply.

e. Government policies might regulate fee arrangements of financial institutions, terms on which accounts are accepted by institutions, and possibly, marketing practices.

f. Government policies might regulate allowable portfolios.

December 16, 1998 
g. Government would monitor institutions' compliance with whatever rules apply to the accumulation and distribution of account funds.*

h. Auditing, trustee, legal and related functions, to the extent not included above.

December 16, 1998 


\section{Appendix B}

We do the calculation in continuous time. Consider a worker who earns $\mathrm{w}_{\mathrm{s}}$ at time s, assumed to grow exponentially at rate $g$ :

$$
\text { (1) } \quad w_{s}=w_{0} e^{g s} \text {. }
$$

The tax rate on these earnings is $t$. There is a proportional front-load charge of $f$, so that $t(1-f) w_{0} e^{g s}$ is deposited at time $s$. This accumulates until retirement age $\mathrm{T}$. The accumulation occurs at rate $r-c$, where $r$ is the rate of return and $\mathrm{c}$ is the management charge per dollar under management. Thus deposits made at time $s$ have accumulated to $t(1-f) \mathrm{w}_{0} e^{g s} e^{(r-c)(T-s)}$ at $t i m e ~ T$. The total accumulation at time $\mathrm{T}$ is the integral of this expression from time 0 until time $\mathrm{T}$. Integrating, the accumulation depends on $\mathrm{f}$ and $\mathrm{c}$ and (for $g+c$ unequal to $r$ ) is equal to:

(2) $\mathrm{A}[\mathrm{f}, \mathrm{C}]=\mathrm{t}(1-\mathrm{f}) \mathrm{W}_{0} \mathrm{e}^{(\mathrm{r}-\mathrm{c}) \mathrm{T}}\left\{\mathrm{e}^{(g+c-r) \mathrm{T}}-1\right\} /(g+c-r)$.

For $g+c=r$, the accumulation satisfies

(3) $\mathrm{A}[\mathrm{f}, \mathrm{C}]=t(1-f) \mathrm{w}_{0} \mathrm{e}^{(\mathrm{r}-\mathrm{c}) \mathrm{T}} \mathrm{T}$.

For $r$ unequal to both $g+c$ and $g$, the ratio of the accumulation to what it would be without any charges satisfies:

(4) $\mathrm{AR}[\mathrm{f}, \mathrm{C}]=\mathrm{A}[\mathrm{f}, \mathrm{C}] / \mathrm{A}[0,0]$

$$
=(1-f) e^{-C T}\left\{\left(e^{(g+c-r) T}-1\right) /\left(e^{(g-r) T}-1\right)\right\}\{(g-r) /(g+c-r)\} \text {. }
$$

The charge ratio is one minus the accumulation ratio:

(5) $\mathrm{CR}[\mathrm{f}, \mathrm{C}]=1-\mathrm{AR}[\mathrm{f}, \mathrm{c}]$.

Sample calculations are shown in the table.

\section{December 16, 1998}


REFERENCES

Advisory Council on Social Security, 1997. 1994-1996 Advisory Council on Social Security. Findings and Recommendations: Volume I and II.

Arthur Anderson LLP. 1998. "Financial Statements of the Thrift Savings Fund - 1997 and 1998."

Bayer, P., Bernheim, B.D., Scholz, J. 1996. "The Effects of Financial Education in the Workplace: Evidence from a Survey of Employers," National Bureau of Economic Research Working Paper, 5655.

Board of Trustees, Federal Old-Age and Survivors Insurance and Disability Insurance Trust Funds. 1998. 1998 Annual Report. Washington, DC: U.S. Government Printing Office.

Diamond, P. 1992. "Organizing the Health Insurance Market." Econometrica, $60: 1233-1254$.

Diamond, P., 1998, "Economics of Social Security Reform." In Arnold, R.D., M.J. Graetz, and A.H. Munnell (eds.), Framing the Social Security Debate: Values, Politics, and Economics, Washington DC: Brookings Institution for the National Academy of Social Insurance.

Dickson, Joel, 1998, personal communication.

Edey Malcolm, and John Simon, 1998 Australia's Retirement Income System, in Fedlstein, 1998 .

Employee Benefit Research Institute. 1994. "Employment-Based Retirement Income Benefits: Analysis of the April 1993 Current Population Survey." EBRI Special Report SR-25/Issue Brief no. 153.

Levitt, Arthur, 1998, Speech at Harvard University, October 19.

Mitchell, Olivia, 1998, Administrative Costs in Public and Private Retirement Systems, in Feldstein, Martin (ed.), Privatizing Social Security, National Bureau of Economic Research, University of Chicago Press.

Mitchell, O., Poterba, J., Warshawsky, M, and Brown, J. forthcoming. "New Evidence on the Money?s Worth of Individual Annuities." American Economic Review.

National Academy of Social Insurance, 1998, Evaluating Issues in Privatizing Social Security, Report of the Panel on Privatization of Social Insurance, Washington: National Academy of Social Insurance (available at www.nasi.org).

Olsen, Kelly A., and Dallas L. Salisbury, 1998, Individual Social Security Accounts: Issues in Assessing Administrative Feasibility and Costs, EBRI Special Report SR-34 and Issue Brief 203, Washington: EBRI.

Poterba, J., and M. Warshawsky. 1998. The Costs of Annuitizing Retirement Payouts from Individual Accounts. This volume.

December 16, 1998 
Rea, John D., and Brian K. Reid, 1998, Trends in the Ownership Cost of Equity Mutual Funds, Washington: Investment Company Institute Perspective.

Social Security Administration, 1997, Annual Statistical Supplement to the Social Security Bulletin.

Wilson, James Q., 1989, Bureaucracy, Basic Books, Inc.

\section{December 16, 1998}

